\title{
СОЦИАЛЬНЫЕ СТРАСТИ
}

\author{
М.Н. Ефременкова, В.В. Гриценко
}

\section{АНАЛИЗ ДИСКУРСА О МИГРАЦИИ СООТЕЧЕСТВЕННИКОВ В РОССИЮ В СРЕДСТВАХ МАССОВОЙ ИНФОРМАЦИИ}

\begin{abstract}
Аннотация. Предмет исследования - психологическое содержание дискурса на тему миграции соотечественников в Россию в средствах массовой инфоормации (СМИ). Также анализируются реакции читателей на статьи по данной проблематике. В статье приведён анализ дискуссий в сети Интернет, вызванных публикациями про соотечественников, возвращающихся в Россию. Прослеживается изменение тематики статей в зависимости от обстановки и миграционной политики в стране. В работе предпринята попытка отследить описываемые в СМИ проблемы и стратегии адаптации мигрантов-соотечественников в России. Посредством метода контент-анализа публикаций в СМИ изучаются формы подачи информации о мигрантах и особенности создаваемого образа мигранта-соотечественника. Практическая значимость и новизна исследования заключается в исследовании влияния дискурса в СМИ на формирование в общественном сознании образа мигранта-соотечественника. В большинстве рассмотренных статей формируется положительный образ беженца, содержится большое количество практической информации для переселенцев. Представленный в СМИ дискурс настраивает читателей на помощь и сочувствие беженцам-соотечественникам. Контент-анализ публикаций позволил оценить дискурс о мигрантах из Украины, как стабилизирующий и конструктивный. Сделано предположение, что лояльное представление российскими СМИ массовой миграции беженцев, объясняется радикальной националистической ситуацией на Украине. ключевые слова: дискурс о миграции, средства массовой информации, социальные представления, Интернетфорум, соотечественники, контент-анализ, образ России, образ мигранта, образ соотечественника, адаптация мигрантов.
\end{abstract}

Review. The subject of the research is the psychological content of the discourse on migration of fellow citizens into Russia performed through mass media. The authors of the article also anlayze the responses of readers to related articles and researches. They analyze the Internet discussions provoked by articles about fellow citizens going back to Russia. The authors also examine how the main themes of such articles change as the migration policy and Russian environment develop. In their research the authors attempt to trace back the problems and strategies of adaptation of Russian migrans as these are described in mass media. The authors perform the content analysis of mass media publications to study forms of transmitting information about migrants as well as peculiarities of the image of a migrating fellow citizen created by mass media. Practical imortance and novelty of the research are caused by the fact that the authors study the influence of the mass media discourse on building the image of a migrating fellow citizen in public conscience. According to the authors, the majority of the articles being reviewed build a positive image of a refugee and contain a lot of practical information for displaced residents. The discourse presented by mass media encourages readers to help and sympathize fellow citizens who happen to be refugees. The content analysis of publications has also allowed to evaluate the discourse about migrants from Ukraine as stabilising and constructive. The authors make an assumption that the loyal attitude of Russian mass media towards mass migration of refugees is caused by the radical nationalist situation in Ukraine.

Key words: image of Russia, content analysis, fellow citizens, Intert forum, social representations, mass media, discourse on migration, image of migrant, image of fellow citizen, adaptation of migrants.

\section{Введение}

В рамках Указа Президента Российской Федерации от 14 сентября 2012 г. № 1289 «0 реализации
Государственной программы по оказанию содействия добровольному переселению в Российскую Федерацию соотечественников, проживающих за рубежом» принята обновленная Госпрограмма по

Исследование проводится при финансовой поддержке РГНФ в рамках

научно-исследовательского проекта «Свои или чужие: особенности социально-

психологической адаптации соотечественников в России» (грант № 15-06-10188). 


\section{Психология и психотехника 11(86) • 2015}

переселению соотечественников. В соответствии с планом мероприятий по её реализации на территорию России переселилось, в основном из стран ближнего зарубежья, несколько тысяч соотечественников, получивших в официальных документах статус «участник Государственной программы переселения». Численность данной категории населения, как свидетельствуют аналитические обзоры миграционной ситуации и деятельности УФМС России, имеет тенденцию к увеличению.

Так, по состоянию на 1 января 2015 г. с начала реализации Государственной программы соотечественникам выдано 164,3 тыс. свидетельств (вместе с членами семей 355,1 тыс. чел.). Только за второй квартал 2015 г. соотечественникам оформлено 26 тыс. свидетельств участника Государственной программы, в которые включено 59,1 тыс. чел., что в 2,0 раза больше оформленных свидетельств за аналогичный период прошлого года [1; 2].

Общественное сознание в ответ на происходящие на территории РФ миграционные потоки так или иначе вырабатывает определённые представления о причинах и последствиях миграции, о личностных особенностях мигрантов и их поведении, которые могут приобретать ярко выраженную эмоциональную окраску. В формировании общественного мнения о миграции и мигрантах и, прежде всего, его эмоциональной составляющей нельзя недооценивать влияние средств массовой информации. Хотя СМИ являются важным средством борьбы с расизмом и ксенофобией, предрассудками и предубеждениями, они в то же время могут способствовать возникновению и усилению подобных взглядов.

О необходимости ответственного подхода со стороны журналистов при освещении проблем иммигрантов, о важности формирования в информационном пространстве адекватного образа мигранта говорят не только правозащитники, научная общественность, но и высокопоставленные чиновники соответствующих ведомств. Так, ещё в 2009 г. глава подмосковного Управления Федеральной миграционной службы РФ Олег Молодиевский призвал журналистов более взвешенно освещать ситуацию с мигрантами и не создавать их негативный образ. «Пользы от мигрантов для нас значительно больше, чем мы порой преподносим, - заявил глава управления, выступая на пресс-конференции перед журналистами. Между тем, благодаря некоторым СМИ, обычный человек, ещё с утра посмотрев телевизор или почитав газету, уже негативно себя настраивает в отношении иностранцев, приехавших сюда работать на нас» [3].
Зачастую авторы публикаций выражают не собственные мнения, а вынуждены отражать позицию редакции, предполагать реакцию аудитории, принимать во внимание социальные стереотипы. В то же время, журналисты имеют возможность формировать убеждения, влиять на стереотипы, ценности читателей. В последние годы в массовом сознании формируется стереотип, связанный с понятием мигрант. Аудитории навязывается клишированная, упрощённая оценка миграции и мигрантов. В общественном сознании вырабатываются стереотипы и в отношении «чужих», и в отношении «своих», но образ «чужих» в большей мере оказывается пристрастным и односторонним. Во многом на формирование данного стереотипа оказывает влияние распространение в средствах массовой информации дискурса на тему миграции в Россию граждан других государств (в большей степени из стран СНГ).

Цель нашего исследования - изучение психологического содержания дискурса в СМИ на тему миграции в Россию соотечественников, формирующего в общественном сознании соответствующий образ мигранта-соотечественника. Для реализации данной цели были поставлены следующие задачи:

- проследить хронологию публикаций по теме миграции соотечественников в Россию, выделить тематические блоки статей;

- выделить обобщенный образ соотечественника, вернувшегося на Родину, формируемый СМИ;

- проанализировать проблемы и стратегии адаптации мигрантов-соотечественников к реалиям РФ;

- $\quad$ отметить реакцию читателей на публикации по данной теме посредством контент-анализа сообщений на форумах.

Под «образом соотечественника» понимается совокупное представление о мигранте, которое создаётся различными субъектами взаимодействий по поводу миранта как объекта содержания коммуникации. Любой образ является сложным социально-психологическим феноменом, включающим в себя множество характеристик. Образ - это «форма отражения объекта в сознании человека. На чувственной ступени познания образами являются ощущения, восприятия и представления, на уровне мышления - понятия, суждения, концепции, теории» [4, с. 432].

По мнению директора Левада-центра Л.Д. Гудкова, «природа этнических фобий или неприязни к мигрантам представляет собой защитную архаическую реакцию на реальные или вообража- 


\section{Социальные страсти}

емые угрозы в ситуациях, когда у населения, по его мнению, ограничены ресурсы выживания или возможности сохранения своих позиций или интересов» [5]. Мигранты и принимающий социум формируют взаимные социальные образы. При эмоционально-нейтральных образах взаимодействие облегчается, становясь в большей степени бесконфликтным и предсказуемым. Если же в обоюдных представлениях присутствуют оценочные характеристики, а в обобщённых образах - эмоционально насыщенные метафорические черты, то перспективы взаимодействия проблематизируются [6]. Социальное осмысление порождает различные стереотипы, фобии, мифы. Обобщённые социальные представления при доминировании стереотипизированных образов влияют на степень доверия и, следовательно, выстраивание определённого способа взаимодействий [7]. Образ мигранта - это совокупность рациональных и иррациональных характеристик, базирующихся на оценках, ассоциациях, ощущениях [8]. Отношение к мигранту всегда двойственно, оно складывается из симпатии и антипатии. Образ мигранта не только складывается на базе обширной социальной практики и непосредственного наблюдения, но и сознательно формируется в процессе проявления так называемого общественного мнения, поэтому данный образ ориентирован на самую широкую аудиторию [9]. Пресса не столько непосредственно формирует, сколько помогает становлению относительно сложившегося в обыденном сознании образа [6].

Материалы и методы. Был проведён обзор публикаций СМИ по теме возвращения на родину соотечественников в период с 01.06.2014 г. по 01.08.2015 г. Дискурс о мигрантах может реализовываться в различных жанрах: информационная заметка, аналитическая статья, электронные чаты и форумы. Отбор ресурсов для анализа был основан на рейтинге цитируемости за 1 квартал 2015 г., составленном компанией «Медиалогия» (http:// www.mlg.ru/ratings/federal_media/). Просматривались публикации по данной проблеме в следующих газетах: «КомерсантЪ», «Известия», «Ведомости», «Российская газета», «Комсомольская правда». Мы исходили из тезиса о том, что данные издания в силу их массовости, популярности, оказывают значительное влияние на формирование социальных представлений о мигрантах. Также нас интересовали новостные подборки по теме соотечественников-мигрантов на Интернет-ресурсах с высоким рейтингом цитируемости - rbc.ru, lenta.ru и gazeta. ru. Для создания более всесторонней картины нами был проведён обзор сайтов, выдаваемых по- исковыми системами Google и Яндекс на запросы типа «русские мигранты», «помощь беженцам», «беженцы из Украины», «русские возвращаются в Россию», «соотечественники возвращаются на родину» и т.п.

Во всем многообразии описаний и дискуссий нам было важно выделить проблематику, стратегии адаптации, которые характерны для вернувшихся в Россию соотечественников, восприятие их россиянами и соответственно образ соотечественника, который транслируется аудитории. Были рассмотрены статьи, описывающие взаимодействие местного населения и властей с переселенцами. Особый интерес представляли для нас публикации, описывающие проблемы соотечественников из Украины, так как подавляющая масса статей про переселенцев за рассмотренный период была посвящена именно злободневной проблеме беженцев из Украины. Нестабильная политическая ситуация и беспорядки вынуждают многих соотечественников и членов их семей решиться на переезд из Украины в Россию.

Результаты и их обсуждение. Публикации по проблемам беженцев из Украины можно условно отнести к двум этапам (временные рамки зависят от конкретного региона РФ).

На этапе, который можно обозначить как «прибытие основного потока беженцев», СМИ информировали население о подготовке властей к приёму беженцев, о количестве людей, прибывающих в Россию, о размещении и нуждах беженцев.

Старший научный сотрудник Института социологии РАН Леонтий Бызов в интервью газете «Коммерсант» отметил, что «мощная пропаганда» власти ориентирована на то, чтобы вызвать сочувствие к беженцам у россиян. По его мнению, поэтому люди проявляют готовность помочь тем, кто покинул свои дома и приехал в Россию. «Если эта пропаганда не будет поддерживаться, волна сочувствия сойдёт на нет, россияне забудут про беженцев, возможно, они даже будут раздражать граждан», - считает Л. Бызов. Он отметил, что у людей «короткая память», к системной работе по поддержке беженцев они ещё не готовы. «Что касается наплыва беженцев, для ряда регионов ситуация критическая, с таким мы ещё не сталкивались, - отмечает социолог. - Но украинцы - люди близкой к нам культуры, поэтому с ассимиляцией проблем возникнуть не должно, социокультурного отторжения не будет» [10]. Многие журналисты используют в своих статьях апелляцию к братству народов России и Украины для прорисовки не чуждого, не враждебного, а родственного образа мигранта. 


\section{Психология и психотехника 11(86) • 2015}

В большом количестве встречаются призывы к сбору гуманитарной помощи, описания тяжелого положения прибывающих. СМИ тем самым формируют образ беженца, повышая лояльность к нему и призывая оказывать посильную помощь. Характерно, что журналисты, не имеющие на данном этапе в большинстве своём возможности общаться с реальными беженцами, создают обобщённый образ. Используются такие эмоциональные определения, как «потерянный», «убежавший от войны», «нуждающийся», «бедный», «беглец», «жертва войны» и т.п. Характерный пример статьи такого рода - «Встреча. Рассказ смолянки о встрече украинских беженцев» [11].

В целом ряде статей наблюдается описание мигрантов как неодушевлённой массы, потока, хлынувшего в Россию, что может способствовать закреплению в сознании россиян предвзятого стереотипа, боязни вторжения «чужих». В то же время, образ России как принимающей страны персонифицируется, создаётся образ России гостеприимной, щедрой, многострадальной. Отношение к такому гостеприимству зависит, вероятно, от восприятия гражданином степени ограниченности социальных благ в стране. Если у человека есть убеждённость, что жизнь в России тяжёлая, население бедное, то поток мигрантов, очевидно, вызовет тревожность, напряжение и раздражение. На основе общего анализа СМИ можно выделить два преобладающих образа мигранта.

Первый образ оценивается негативно, хотя зачастую в завуалированной форме. В его характеристиках выделяются угроза экономическому благосостоянию коренного населения, обострение ситуации с социальными благами (рабочие места, места в садах и школах и т.п.). Сформировавшийся отрицательный социально-психологический фон, созданный журналистами, транслируется аудитории, увеличивая в ней существующие тревогу, недоверие и прочие негативные эмоциональные составляющие ментальных установок в отношении мигрантов [12]. В большинстве же публикаций мигрант наделяется позитивными качествами, которые должны вызывать у читателя сочувствие в связи с большими трудностями адаптации.

Характерны для публикаций этого периода и попытки объяснить причины переселения, показать всю тяжесть положения русских на Украине. Здесь чувствуется стремление популярно объяснить суть политической ситуации на Украине и обосновать, почему люди вынуждены покидать свою страну и почему им нужно помогать. В статьях данного этапа приводятся исторические экс- курсы, объясняющие русские корни беженцев, иллюстрирующие притеснение этнических русских радикальными группировками, прослеживающие ограничения последних лет в распространении русского языка на Украине. Активно описываются конкретные меры помощи беженцам - сбор одежды, организация бесплатного питания, социальная помощь в оформлении документов, поиске работы, устройстве в детские сады и т.п.

На втором этапе публикаций по проблемам беженцев из Украины, условно названном нами, как «адаптация, интеграция соотечественников в России», когда переселенцы из Украины перестали быть в новинку, журналисты обратили более пристальное персонифицированное внимание на них и попытались проанализировать проблемы их адаптации. Статьи данного периода описывают конкретные истории семей переселенцев: «Обустройство временного убежища. Как граждане Украины устраиваются в России» [13]; «Общее горе. Как украинские беженцы ищут и находят приют в России» [14]; «Погостили на войне. Кто и как спасает детей с Украины» [15]. Данные статьи отражают толерантность к мигрантам и стремление авторов публикаций понять объективные причины их переезда в Россию, сочувственно отнестись к проблемам, с которыми сталкиваются беженцы. Такая эмпатия, зачастую, встречается у тех авторов, которые для сбора достоверной информации становились участниками взаимодействий с мигрантами различных ситуациях.

Авторы активно апеллируют к образу соотечественника, вернувшегося на родину из-за невозможности жить на Украине, из-за притеснения со стороны властей. Популярны статьи, описывающие тёплый приём российскими семьями беженцев, благодарственные речи за помощь в обустройстве, предоставлении жилья и работы (например, статья «В Смоленске приютили семью беженцев из Украины» [16]).

Другие статьи описывают «отрезвляющую российскую реальность» - бюрократические проволочки при оформлении документов, отсутствие подходящей работы, бедность и неустроенность жизни в российской глубинке. Например, следующие статьи: «В ответе за надежду» [17]; «Отрезвляющая смоленская реальность для беженцев из Украины» [18].

Часть авторов видит проблему в чрезмерной требовательности и пассивности беженцев, описывает конфликтные ситуации с местным населением. Вот как описывает отношение к себе местных жителей украинка: «Местные по-разному относятся к переселенцам. Одни жалеют, поддерживают, 


\section{Социальные страсти}

другие говорят о том, что им и самим места мало. А тут ещё нужно кормить других. В разговорах фигурировали и 800 мифических рублей, которые теоретически где-то кому-то из беженцев якобы давали...» [19]. Ряд статей вносит «ложку дёгтя» в описание адаптации переселенцев - улавливают слухи (зачастую беспочвенные) о нежелании беженцев трудоустраиваться из-за хорошего государственного обеспечения, о якобы выселении студентов из общежития для заселения беженцев [20], о больших пособиях беженцев «из кармана налогоплательщика» и т.п. Чаще всего такие слухи озвучиваются в статьях в Интернет-ресурсах, при отсутствии фильтрация информации, а затем опровергается официальными СМИ.

Присущий местному населению страх, что мигранты отнимут и так ограниченные социальные блага, проявляется в ряде публикаций [21]. Официальные СМИ пытаются акцентировать внимание населения на том, что беженцы не несут угрозу на рынке труда, занимают дефицитные вакансии и трудоустраиваются на селе (например, обзор экономических последствий наплыва беженцев в статье «Из жизни отъезжающих» [22]). Как пишет в своей статье председатель исполкома «Форума переселенческих организаций» Лидия Графова: «Но зачем же опустошать другие регионы, когда к нам едут соотечественники, близкие по языку и культуре, готовые специалисты, многие - высококвалифицированные» [23].

В СМИ формируется образ беженца, нуждающегося в помощи и поддержке и официальных структур, и простых обывателей. На ряде информационных ресурсов появляются целые разделы, посвящённые консультированию соотечественников по бюрократическим вопросам переселения в РФ (например, http://subsidii.net/, http://www.9111.ru и мн. др.). На таких сайтах вопросы юристам задают как беженцы, так и ещё планирующие переселиться в РФ граждане Украины. Рассматриваются вопросы получения статуса беженца и гражданства, оформления и восстановления документов, таможенной регистрации имущества, поиска жилья и работы.

Также в сети Интернет в изобилии представлены сайты, спекулирующие мнением масс, утрирующие одностороннее восприятие проблемы беженцев. Читатель, осуществляя навигацию по сайтам, опирается либо на собственное критическое мышление, либо на сложившиеся политические установки и стереотипы [24]. Пример для сравнения - сайты http://ruskline.ru и http://glavred.info, освещающие проблему беженцев кардинально противоположными эпитетами [25; 26].
Современные СМИ стали более интерактивными, благодаря Интернет-версиям периодических изданий с возможностью комментировать статьи читателями. В социальных сетях, на форумах ежедневно разгораются обсуждения в специальных группах, заметках, статусах, касающихся проблем на Украине. Даже самые нейтральные по содержанию статьи зачастую становятся поводом для эмоциональных дискуссий на тему переселения, национального вопроса, отношений России и Украины. Лозунги типа «Россия для русских» в таких обсуждениях находят, вероятно, большие отклики у социально незащищенных слоев населения, опасающихся за нехватку рабочих мест. Статьи, описывающие трудности адаптации мигрантов, вызывают у таких читателей раздражение и негодование.

Мы проанализировали комментарии, которые оставляли в подобных обсуждениях наши соотечественники, приехавшие в Россию или же планирующие это сделать.

Их можно разделить на ряд преобладающих тем:

- Конкретные просьбы о помощи - кратко описывается возраст, образование членов семьи, перечисляется, чего не хватает (одежда, техника, жильё, работа). Зачастую обращаются к русским с просьбами «не бросать своих», упоминают о братстве, перечисляют русских родственников.

- Конкретные просьбы помочь планирующим переехать в Россию - консультация по процедуре переезда, попытки найти конкретное место, куда поехать, где работать и жить.

- Благодарность за оказание помощи в переселении местным жителям, описание дальнейших планов «мирной жизни» в России. Проявление первичного позитивного настроя на ассимиляцию с местным населением, планирование жизни в России.

- Описание ужасов войны, переживания по поводу оставшихся родственников. Такие участники обсуждения чаще всего планируют возврат на Украину, выказывают тревогу из-за неопределённости ситуации.

- Недовольство принимающей стороной - бюрократическими процедурами, неприветливым местным населением, отсутствием ожидаемой социальной поддержки, безработицей и т.п.

- Участие в исторических дискуссиях на тему русских на Украине, политические споры о принадлежности Крыма и судьбе Донбасса.

- Описание семейных конфликтов на национальной почве («уехали в Россию - родственники на Украине отказались от нас»). 


\section{Психология и психотехника 11(86) • 2015}

Если говорить об освещении в СМИ проблем соотечественников-переселенцев из европейских стран, стран СНГ, Латинской Америки и др., то нельзя не заметить небольшое количество и формализм статей по данной теме [27; 28].

Наибольшее количество упоминаний русских, вернувшихся на родину, приходится на статьи 2012 г., когда активно освещалась государственная программа по переселению «Соотечественники». В данных статьях авторы проводят статистические обзоры по количеству вернувшихся, географии переселения, процедуры оформления и социальной поддержки мигрантов. Авторы статей отмечают, что Программа дорабатывается и снимает ряд административных барьеров и упрощает процедуру возвращения людей на историческую родину из-за рубежа.

В публикациях по данной теме можно проследить анализ понятия «соотечественники», размышления о том, какие категории мигрантов предполагаются целевой аудиторией программы по переселению. Руководитель Управления Федеральной миграционной службы по Карелии Татьяна Жураховская так описала в интервью образ участника данной программы: «Сам принцип участия в программе предполагает, что человек, который переселяется, является нашим соотечественником: разделяет идеалы, устои Российской Федерации, владеет русским языком, считает себя россиянином по духу. Понятие это очень широкое» [29]. Такая широкая трактовка приводит к уравнению всех категорий переселенцев. Если вдуматься, российские соотечественники - это и граждане РФ, проживающие за рубежом, и потомки коренных народов РФ, и все граждане бывшего СССР. Таким образом, население всего постсоветского пространства - это российские соотечественники. Подобное обобщение, вероятно, было применено искусственно для позиционирования российского влияния на территории бывшего Советского Союза, но особой практической пользы оно не приносит. Как только соотечественник приезжает в Россию, он автоматически приобретает статус мигранта и становится в один ряд с мигрантами «не соотечественниками». Так СМИ описывают ряд проблем в получении гражданства переселившимися соотечественниками. Вот как объясняет наш соотечественник, приехавший из Молдавии, почему за 7 лет жизни в России он до сих пор не гражданин РФ: «Я устал объяснять: несмотря на то, что я - русский, я не имею никаких преимущественных оснований для получения российского гражданства. Только через стандартную процедуру, которая длится не менее пяти лет. Вот как это происходит: оформляем квоту на РВП (разрешение на временное пребывание) - очередь занимают за месяцы, стоять приходится сутками на морозе. Через полгода приходит положительное или отрицательное решение. Потом, спустя 6 месяцев, если, конечно, решение положительное, можно подать заявление на вид на жительство при наличии регистрации на три года. И, получив вид на жительство, следует ждать еще пять лет. В общей сложности может пройти не менее 7-8 лет» [30]. Таким образом, среди публикаций СМИ на тему данной государственной программы, несмотря на её успешную реализацию, встречаются и критические очерки, описывающие бюрократические проблемы, с которыми сталкиваются соотечественники при переселении в Россию.

Большое количество статей посвящено возврату в страну «русских немцев». В 90-х гг. ХХ в. в Германию переселились несколько миллионов «русских немцев». В последние годы происходит обратная волна эмиграции - по статистике каждая двадцатая семья возвращается в Россию, называя её своей настоящей родиной. Рассмотренные нами статьи содержат исторический экскурс и большое количество семейных историй и интервью реальных переселенцев из Германии. Отвечая на вопросы журналистов о причинах возврата в Россию, мигранты называют трудности с поиском работы, невозможность организации хозяйства, негативное отношение коренных немцев, языковой барьер, разница менталитетов. Несколько из описанных семей переехали в Россию, чтобы воспитывать детей, не принимая западную систему воспитания и образования. Но даже те, кто сумел полностью адаптироваться в Германии, хотят вернуться обратно. По словам одного из мигрантов, многие соотечественники хотели бы вернуться, но для этого надо себя переломить, осознать, что был не прав. Вместо этого проще убедить себя, что правильным решением было уехать, а для подтверждения выискивают и смакуют дурные новости о России [31]. Часто встречающийся лейтмотив в сравнении мигрантами двух стран, заключается в том, что в Германии быть бедным хуже, чем в России. Те, кого в Германии считают бедными, в России относятся к средней прослойке. В России больше людей с низким достатком, но у них есть возможность вести подсобное хозяйство и не зависеть от социальной помощи. Сложно адаптироваться нашим соотечественникам и к строгому соблюдению в Европе законов и норм: «Трава не так подстрижена - штраф, дерево выросло больше, чем нормами предусмотрено, - штраф... Видишь, здесь я свой дом могу переделать, как хочу, а там за это - штраф! Все 


\section{Социальные страсти}

судятся со всеми... Вы хотите такую жизнь?» [32] Чужд нашим соотечественникам индивидуализм немцев, разница в понятиях о дружбе, любви. Анализируя интервью мигрантов, можно обобщить следующее: главных поводов вернуться в Россию два - ностальгия и стремление к свободе. «Здесь мы по-настоящему свободны», - говорят многие. И речь идёт не о политических свободах, а об отсутствии жёсткого регламентирования жизни.

Альтернативный взгляд на возвращающихся в Россию представлен в статье “"Русские немцы” в Германии: уезжают только лентяи» [33]. Статья написана нашим бывшим соотечественником, живущим в ФРГ в ответ на публикацию «Почему возвращаются "русские немцы”?» [34]. Автор письма классифицирует «русских немцев» по степени адаптивности в Германии. Первая категория, самая распространённая - наиболее преуспевающие в Германии простые, трудолюбивые люди, умеющие работать и зарабатывать. Вторая - лентяи. Из второй категории - многие возвращаются в Россию, другие живут бедно, некоторые опустились, живут в ночлежках. И третья категория - крайне редкие представители интеллигенции, люди редких профессий. Самое тяжёлое положение, по словам автора письма, у третьей категории. Утеря статуса, необходимость подтверждать диплом, необходимость хорошо владеть языком не позволяет им с лёгкостью влиться в социум на желаемом уровне жизни. О тех, кто возвращается в Россию, автор отзывается так: «Ни один не делает этого из патриотических чувств. Я, по крайней мере, таких не знаю. Основных мотива два. Первый: свобода, понимаемая как безответственность. “Да я буду жить без света, газа и воды, зато сосед не будет доносить на меня, когда трава на газоне выросла выше положенного уровня. И сарай я построю такой, какой захочу". Остальные возвращаются, чтобы зарабатывать больше. Эти едут на подготовленные друзьями и родственниками места и по прибытии входят в чужой готовый бизнес» [33]. Это обобщение является показательным. Нами были прослежены комментарии к статьям по данной теме, которые оставляют на электронных версиях печатных СМИ. Зачастую, соотечественники, оставшиеся за рубежом, характеризуют вернувшихся именно в таком ключе - уехали, потому что лентяи, потому что не амбициозны, потому что не сумели адаптироваться.

В статьях по данной тематике прослеживается сходный образ вернувшихся из Европы соотечественников: они более педантичны, хозяйственны, хорошо знают свои права и добиваются от властей их соблюдения. По отзывам самих мигрантов, мест- ное население относится к ним по-разному - настороженно, дружелюбно, с любопытством перенимают новшества в ведении хозяйства [35; 36; 37].

Интересный обзор мотивов возвращения из Европы в Россию приведён в статье «Почему в Москву возвращаются те, кто долго жил за границей» [38]. В ней описаны шесть историй жизни за рубежом наших соотечественников в формате ответа на три вопроса: почему уехали, чем занимались за границей, почему вернулись в Россию. Герои статьи - молодые, образованные, амбициозные люди, которые, получив опыт, знания, материалы, сертификаты за границей, вернулись в Россию. «Возможно, я просто скучал по своим близким, но мне кажется, что европейцы всё-таки совсем другие. При этом все бытовые трудности перестали казаться такими уж важными. Я перестал так сильно чувствовать разницу между европейским благополучием и российской неустроенностью, перестал жаловаться» [38]. Они, анализируя преимущества западного и отечественного общества для самореализации и создания собственного бизнеса, замечают следующее: «В США его можно начать с максимальными грантами и минимальными собственными средствами, а там уж как получится. В России же надо выложить суммы в десятки раз больше, и каждая деталь бизнеса будет обходиться дороже. Но здесь гигантский потенциал роста, а в США часто закрадываются мысли, что всё уже придумали и действительно хорошо» [38]. Почти все герои статьи выбрали для жизни Россию по причине «человеческого фактора», так, например, высказался в интервью вернувшийся из Франции соотечественник: «Я по-другому посмотрел на Россию. Во-первых, я понял, что такое русская душа. Это твои друзья, которые достаточно отчаянны, чтобы совершать какие-то необдуманные поступки, они, может, люди необязательные, но всегда помогут, если ситуация критическая» [38].

В Интернете мы нашли ссылку на сайт www. remigrant.ru, зарегистрированный русскоязычными студентами из Германии, предоставляющий информацию соотечественникам, которые хотят вернуться в Россию (в настоящий момент сайт не функционирует). Интернет-портал www.remigrant. ru давал соотечественникам информацию и юридическую консультацию по переселению. По опросу Интернет-портала www.remigrant.ru, проводимому в 2007 г., 34,15\% от общего числа соотечественников за рубежом называют основным поводом для возвращения «лучшие перспективы для жизни в России». 21,95\% хотят переселиться из-за «непризнания своей квалификации», 19,51\% - изза «другого менталитета», 14,63\% - из-за отсут- 


\section{Психология и психотехника 11(86) • 2015}

ствия работы и лишь 2,44\% называют причиной «трудности с языком» [39].

Как считает Жанна Зайончковская, известный специалист в области изучения миграции, в настоящее время на политическом уровне риторика в отношении мигрантов меняется, она практически полностью затихла. Такое снижение внимания к проблеме мигрантов исследовательница связывает с ситуацией на Украине: «Всплеск национализма в соседнем государстве, вне зависимости от его трактовки, вызвал у граждан России определённый ужас к ситуации нетерпимости в обществе» [40]. Появился наглядный пример последствий конфликтов на национальной почве, который напугал многих, в том числе сторонников националистических движений. «С точки зрения отношения российского общества к мигрантам важнее оказывается не державный патриотизм, насаждающийся в СМИ, а тот образ событий на Украине, который формируют российские СМИ. Предлагаемая российскому телезрителю картина всплеска оголтелого радикального национализма в соседней стране оказывается важнее, чем проблема собственного национального сознания. Это, на мой взгляд, приводит к тому, что лозунг «Россия для русских» уходит на задний план», - отмечает директор Сахаровского Информационно-исследовательского центра «Сова» [40].

В СМИ одновременно позиционируются две противоположные тенденции. С одной стороны, отмечается важность миграции соотечественников для России в связи с дефицитом трудовых ресурсов и уменьшением населения, позиционируется необходимость защиты притесняемых за рубежом россиян. С другой стороны, прослеживается призыв к «охранной» стратегии и регулированию потока мигрантов. Позиция автора в отношении мигрантов-соотечественников проявляется в публикации через использование либо акцента на сходстве и на единстве русского народа, либо на необходимости защищать и так ограниченные социальные блага.

\section{Заключение}

На основе анализа публикаций в российских средствах информации можно выделить следующие особенности дискурса о миграции соотечественников в Россию:

1. Наибольшее количество публикаций по теме миграции соотечественников в Россию, приходится на 2012 г., когда начала активно реализовываться государственная программа по переселению «Соотечественники». В 2014 г., в связи с событиями на Украине, интерес СМИ к освещению миграции соотечественников в России усилился.

2. Тема мигрантов-соотечественников из Украины является актуальной для российского общества, что порождает высокий спрос на статьи на данную тему. Многие статьи на электронных ресурсах вызывают оживленные дискуссии пользователей.

3. В СМИ практически не встречается нейтральных по направленности статьей. В заголовках прослеживаются оценочные интонации от сочувствия тяжёлому положению беженцев, до тревоги перед их массовым заселением в Россию.

4. Дискурс о миграционных процессах в стране зависит от текущей миграционной политики государства и зачастую носит пропагандистский оттенок. Авторы, в большинстве своем, отражают в своих статьях статистические данные о миграции, призывают население к активной помощи переселенцам, показывают активность действующей власти в решении проблем соотечественников.

5. Радикальная националистическая ситуация на Украине послужила стимулом для более лояльного освещения журналистами массовой миграции в Россию. На примере соседней страны становятся опасными лозунги типа «Россия для русских».

6. Если проанализировать обобщенный образ мигранта-соотечественника, то можно выделить следующие его составляющие: соотечественники - это преимущественно выходцы с Украины. Соотечественники - это жертвы военных действий и политических репрессий, в большинстве своём простые, честные и трудолюбивые люди, оказавшиеся в сложной жизненной ситуации, а потому заслуживающие помощи и сострадания. Соотечественники - это «нахлебники» и обуза для российского общества, незаслуженно посягающие на «лакомый кусок российского пирога», а потому вызывающие у некоторой части населения недовольство и агрессию.

7. В публикациях, посвящённых мигрантам-соотечественникам из европейских стран, описываются конкретные мотивы возвращения и трудности их адаптации в России. Наиболее часто называемые в интервью причины возврата в Россию - это проблемы с трудоустройством, трудности в организации хозяйства на прежнем месте жительства, негативное отношение местного населения, языковой барьер, разница менталитетов русских и европейцев, а также лучшие 


\section{Социальные страсти}

перспективы для бизнеса в России. Также в публикациях и в комментариях к ним фигурирует мнение, что уезжают обратно в Россию ленивые, пассивные, неадаптивные люди.

8. В итоге дискурс о соотечественниках в целом и о соотечественниках из Украины, в частности, носит стабилизирующий и конструктивный характер - формирует позитивный образ соот- ечественника, предоставляет большое количество практической информации для переселенцев, настраивает на помощь и сочувствие россиян. Однако не следует пренебрегать и содержанием дискурса о мигрантах в СМИ, который может приводить к активизации негативной эмоциональной составляющей общественного сознания.

\section{Список литературы:}

1. Мониторинг реализации Государственной программы по оказанию содействия добровольному переселению в Российскую Федерацию соотечественников, проживающих за рубежом, на территориях вселения субъектов Российской Федерации в IV квартале 2014 г. (URL: http://www.fms.gov.ru/programs/fmsuds/monitoring/4_kv_2014.pdf (дата обращения 20.10.2015))

2. Мониторинг реализации Государственной программы по оказанию содействия добровольному переселению в Российскую Федерацию соотечественников, проживающих за рубежом, на территориях вселения субъектов Российской Федерации в I квартале 2015 г. (URL: http://www.fms.gov.ru/programs/fmsuds/monitoring/1kv_2015.pdf (дата обращения 20.10.2015))

3. ФМС Подмосковья: СМИ настраивают москвичей против мигрантов. 30 января 2009 г. (URL: http://www.newsmsk. com/article/30jan2009/obraz_migrant.html (дата обращения 12.09.15))

4. Философский энциклопедический словарь / Редкол.: С.С. Аверинцев, Э.А. Араб-Оглы, Л.Ф. Ильичев и др. 2-е изд. М.: Сов. энциклопедия, 1989.

5. Гудков Л.Д. Смещенная агрессия: отношение россиян к мигрантам // Вестник общественного мнения. 2005. Ноябрьдекабрь. № 6(80). С. 60-77.

6. Титов В.Н. О формировании образа этнического иммигранта (анализ публикаций прессы) // Демоскоп Weekly. 22 ноября - 5 декабря 2004. № 179-180. (URL: http://www.demoscope.ru/weekly/2004/0179/analit03.php (опубликовано: СОЦИС. 2003. № 11))

7. Мукомель В.И. Российские дискурсы о миграции // Вестник общественного мнения. 2005. № 1(75). С. 49-58.

8. Бакумова Е.В. Речевые маркеры социально-политической идентификации // Языковая личность: проблемы когниции и коммуникации. Волгоград, 2001. С. 236-241.

9. Иссерс О.С. Речевое воздействие в аспекте когнитивных категорий // Вестник Омского университета. 1999. Вып. 1. С. 74-79.

10. Россияне готовы пустить украинских беженцев в свои дома // Kommersant.ru. 17 июля 2014 г. (URL: http://www. kommersant.ru/doc/2526779 (дата обращения 12.09.15))

11. Встреча. Рассказ смолянки о встрече украинских беженцев // Readovka.ru. 7 июля 2014 г. (URL: http://readovka.ru/ blog/society-and-life/2479-vstrecha (дата обращения 12.09.15))

12. Гудков Л.Д. Смещенная агрессия: отношение россиян к мигрантам // Вестник общественного мнения. 2005. Ноябрьдекабрь. № 6(80). С. 60-77.

13. Обустройство временного убежища. Как граждане Украины устраиваются в России // Lenta.ru. 15 июля 2014 г. (URL: http://lenta.ru/articles/2014/08/19/refugees/ (дата обращения 12.09.15))

14. Общее горе. Как украинские беженцы ищут и находят приют в России // Rg.ru. 1 aвгуста 2014 г. (URL: http:// rg.ru/2014/07/31/bejenci-site.html/ (дата обращения 12.09.15))

15. Погостили на войне. Кто и как спасает детей с Украины // Rg.ru 9 июля 2014 г. (URL: http://rg.ru/2014/07/09/ astahov-site.html/ (дата обращения 12.09.15))

16. В Смоленске приютили семью беженцев из Украины // Smol.kp.ru 17 июня 2014 г. (URL: http:// smol.kp.ru/online/ news/1764305/) (дата обращения 12.09.15))

17. В ответе за надежду // Lenta.ru 19 августа 2014 г. (URL: http://lenta.ru/articles/2014/08/19/refugees/ (дата обращения 12.09.15))

18. Отрезвляющая смоленская реальность для беженцев из Украины // Readovka.ru. 30 июля 2014 г. (URL: http:// readovka.ru/blog/society-and-life/2692-smolensk_biet_s_noska (дата обращения 12.09.15))

19. Беженка из Украины опубликовала свои впечатления от жизни в Смоленске // Smol.kp.ru 18 января 2015 г. (URL: http://www.smol.kp.ru/daily/26329.2/3213306/ (дата обращения 12.09.15))

20. Добро пожаловать или Посторонним вход воспрещён // Readovka.ru. 01 сентября 2014 г. (URL: http://readovka.ru/ blog/society-and-life/3047-dobro-pozhalovat-ili-postoronnim-vhod-vospreshhjon (дата обращения 17.10.15))

21. Макаров М.Л. Динамика социальных представлений в дискурсе // Языковые подсистемы: стабильность и движение: Сб. науч. тр. Тверь: Твер. гос. ун-т, 2001. С. 64-71.

22. Из жизни отъезжающих // Lenta.ru. 14 июля 2014 г. (URL: http://lenta.ru/articles/2014/07/11/bezhentsy/ (дата обращения 17.10.15))

23. Графова Л. Как помочь украинским беженцам обустроиться в России // Rg.ru. 13 сентября 2015 г. (URL: http://www. rg.ru/2015/08/02/bezhency.html (дата обращения 12.09.15))

24. Слышкин Г.Г. От текста к символу: лингвокультурные концепты прецедентных текстов в сознании и дискурсе. М.: Academia, 2000.128 c.

25. Я не собираюсь возвращаться. Мы всегда считали себя русскими // Ruskline.ru 3 июля 2014 г. (URL: http://ruskline.ru/ news_rl/2014/07/03/ya_ne_sobirayus_vozvrawatsya_my_vsegda_schitali_sebya_russkimi/ (дата обращения 17.10.15)) 


\section{Психология и психотехника 11(86) • 2015}

26. Беженцы возвращаются из РФ на Донбасс: устали от нищеты российской глубинки и пьянства pусских // Glavred. info. 7 апреля 2015 г. (URL: http://glavred.info/zhizn/bezhency-vozvraschayutsya-iz-rf-na-donbass-ustali-ot-nischetyrossiyskoy-glubinki-i-pyanstva-russkih-312468.html (дата обращения 17.10.15))

27. Бывшие соотечественники возвращаются в Россию // News2.ru. 8 октября 2012 г. (URL: http://news2.ru/ story/364477/ (дата обращения 17.10.15))

28. Соотечественники возвращаются в Россию // Windowrussia.ruvr.ru. 4 ноября 2012 г. (URL: http://windowrussia.ruvr. ru/2012_11_04/Sootechestvenniki-vozvrashhajutsja-v-Rossiju/ (дата обращения 17.10.15))

29. В Карелию возвращаются соотечественники из Таджикистана, Молдовы и Грузии // Russkie.org. 21 февраля 2013 г. (URL: http://www.russkie.org/index.php?module=fullitem\&id=28559 (дата обращения 17.10.15))

30. Возвращение соотечественников в Россию ускоряется // Odnako.org. 10 октября 2013 г. (URL: http://www.odnako. org/blogs/vozvrashchenie-sootechestvennikov-v-rossiyu-uskoryaetsya/ (дата обращения 17.10.15))

31. Русские немцы покидают историческую родину и возвращаются в Россию // Rg.ru. 8 июня 2007 г. (URL: http://www. rg.ru/2007/06/08/nemci.html (дата обращения 17.10.15))

32. Русские немцы возвращаются в Россию // Ru-an.info. 18 октября 2012 г. (URL: http://ru-an.info/новости/русскиенемцы-возвращаются-в-россию/ (дата обращения 17.10.15))

33. «Русские немцы» в Германии: уезжают только лентяи // Repin.info. 16 ноября 2012 г. (URL: http://repin.info/ nacionalnyy-otvet/russkie-nemcy-v-germanii-uezzhayut-tolko-lentyai (дата обращения 17.10.15))

34. Почему возвращаются «русские немцы»? // Repin.info 30 октября 2012 г. (URL: http://repin.info/nacionalnyy-otvet/ pochemu-vozvrashchayutsya-russkie-nemcy (дата обращения 17.10.15))

35. В Омскую область массово возвращаются русские немцы // Vesti.ru. 22 января 2013 г. (URL: http://www.vesti.ru/doc. html?id=1011698 (дата обращения 17.10.15))

36. Почему люди, покинувшие Россию, все равно возвращаются? // Okno.ca. 12 ноября 2015 г. (URL: http://okno.ca/ choice/pochemu-lyudi-pokinuvshie-rossiyu-vse-ravno-vozvrashhayutsya.html (дата обращения 20.11.15))

37. Долгий путь русских в Россию // Nbm.md. 25 декабря 2013 г. (URL: http://nbm.md/news/main/dolgij_putj_russkuh_v_ rossiyu/default.aspx (дата обращения 20.11.15))

38. Почему в Москву возвращаются те, кто долго жил за границей // The-village.ru. 10 октября 2012 г. (URL: http://www. the-village.ru/village/city/people/117661-vernulis (дата обращения 20.11.15))

39. Наша перспектива - Россия. Почему соотечественники из Германии возвращаются в Россию? // www.russkie.org. 27 сентября 2007 г. (URL: http://www.russkie.org/index.php?id=11242\&module=fullitem (дата обращения 12.09.15))

40. Мигрантов меньше не станет. // Lenta.ru 7 апреля 2015 г. (URL: http://lenta.ru/articles/2015/04/07/migrant/ (дата обращения 12.09.15))

41. Волох В.А., Сулейманова Ш.С. Роль и значение медиаполитики в управлении миграционными процессами // Политика и общество. 2015. № 10. C. 1427-1433. (DOI: 10.7256/1812-8696.2015.10.15424)

42. Петухов А.Ю. Влияние психологических операций на политический процесс в России в условиях информационных войн // Национальная безопасность / nota bene. 2015. № 5. C. 648-655. (DOI: 10.7256/2073-8560.2015.5.16221)

43. Киричёк Е.В. Полиция и средства массовой информации в России: правовое регулирование, проблемы и перспективы взаимодействия // Политика и общество. 2014. № 12. C. 1459-1468. (DOI: 10.7256/1812-8696.2014.12.10197)

44. Пашинян И.А. Контент-анализ как источник оценочной информации в исследовании имиджа России // Политика и общество. 2012. № 4. С. 108-113.

\section{References (transliteration):}

1. Monitoring realizatsii Gosudarstvennoi programmy po okazaniyu sodeistviya dobrovol'nomu pereseleniyu v Rossiiskuyu Federatsiyu sootechestvennikov, prozhivayushchikh za rubezhom, na territoriyakh vseleniya sub"ektov Rossiiskoi Federatsii v IV kvartale 2014 g. (URL: http://www.fms.gov.ru/programs/fmsuds/monitoring/4_kv_2014.pdf (data obrashcheniya 20.10.2015))

2. Monitoring realizatsii Gosudarstvennoi programmy po okazaniyu sodeistviya dobrovol'nomu pereseleniyu v Rossiiskuyu Federatsiyu sootechestvennikov, prozhivayushchikh za rubezhom, na territoriyakh vseleniya sub"ektov Rossiiskoi Federatsii v I kvartale 2015 g. (URL: http://www.fms.gov.ru/programs/fmsuds/monitoring/1kv_2015.pdf (data obrashcheniya 20.10.2015))

3. FMS Podmoskov'ya: SMI nastraivayut moskvichei protiv migrantov. 30 yanvarya 2009 g. (URL: http://www.newsmsk.com/ article/30jan2009/obraz_migrant.html (data obrashcheniya 12.09.15))

4. Filosofskii entsiklopedicheskii slovar' / Redkol.: S.S. Averintsev, E.A. Arab-Ogly, L.F. Il'ichev i dr. 2-e izd. M.: Sov. entsiklopediya, 1989.

5. Gudkov L.D. Smeshchennaya agressiya: otnoshenie rossiyan k migrantam // Vestnik obshchestvennogo mneniya. 2005. Noyabr'-dekabr'. № 6(80). S. 60-77.

6. Titov V.N. O formirovanii obraza etnicheskogo immigranta (analiz publikatsii pressy) // Demoskop Weekly. 22 noyabrya - 5 dekabrya 2004. № 179-180. (URL: http://www.demoscope.ru/weekly/2004/0179/analit03.php (opublikovano: SOTsIS. 2003. № 11))

7. Mukomel' V.I. Rossiiskie diskursy o migratsii // Vestnik obshchestvennogo mneniya. 2005. № 1(75). S. 49-58.

8. Bakumova E.V. Rechevye markery sotsial'no-politicheskoi identifikatsii // Yazykovaya lichnost': problemy kognitsii i kommunikatsii. Volgograd, 2001. S. 236-241.

9. Issers O.S. Rechevoe vozdeistvie v aspekte kognitivnykh kategorii // Vestnik Omskogo universiteta. 1999. Vyp. 1. S. 74-79.

10. Rossiyane gotovy pustit' ukrainskikh bezhentsev v svoi doma // Kommersant.ru. 17 iyulya 2014 g. (URL: http://www. kommersant.ru/doc/2526779 (data obrashcheniya 12.09.15))

11. Vstrecha. Rasskaz smolyanki o vstreche ukrainskikh bezhentsev // Readovka.ru. 7 iyulya 2014 g. (URL: http://readovka.ru/ blog/society-and-life/2479-vstrecha (data obrashcheniya 12.09.15))

12. Gudkov L.D. Smeshchennaya agressiya: otnoshenie rossiyan k migrantam // Vestnik obshchestvennogo mneniya. 2005. Noyabr'-dekabr'. № 6(80). S. 60-77. 
13. Obustroistvo vremennogo ubezhishcha. Kak grazhdane Ukrainy ustraivayutsya v Rossii // Lenta.ru. 15 iyulya 2014 g. (URL: http://lenta.ru/articles/2014/08/19/refugees/ (data obrashcheniya 12.09.15))

14. Obshchee gore. Kak ukrainskie bezhentsy ishchut i nakhodyat priyut v Rossii // Rg.ru. 1 avgusta 2014 g. (URL: http:// rg.ru/2014/07/31/bejenci-site.html/ (data obrashcheniya 12.09.15))

15. Pogostili na voine. Kto i kak spasaet detei s Ukrainy // Rg.ru 9 iyulya 2014 g. (URL: http://rg.ru/2014/07/09/astahov-site. html/ (data obrashcheniya 12.09.15))

16. V Smolenske priyutili sem'yu bezhentsev iz Ukrainy // Smol.kp.ru 17 iyunya 2014 g. (URL: http:// smol.kp.ru/online/ news/1764305/) (data obrashcheniya 12.09.15))

17. V otvete za nadezhdu // Lenta.ru 19 avgusta 2014 g. (URL: http://lenta.ru/articles/2014/08/19/refugees/ (data obrashcheniya 12.09.15))

18. Otrezvlyayushchaya smolenskaya real'nost' dlya bezhentsev iz Ukrainy // Readovka.ru. 30 iyulya 2014 g. (URL: http:// readovka.ru/blog/society-and-life/2692-smolensk_biet_s_noska (data obrashcheniya 12.09.15))

19. Bezhenka iz Ukrainy opublikovala svoi vpechatleniya ot zhizni v Smolenske // Smol.kp.ru 18 yanvarya 2015 g. (URL: http:// www.smol.kp.ru/daily/26329.2/3213306/ (data obrashcheniya 12.09.15))

20. Dobro pozhalovat' ili Postoronnim vkhod vospreshchen // Readovka.ru. 01 sentyabrya 2014 g. (URL: http://readovka.ru/ blog/society-and-life/3047-dobro-pozhalovat-ili-postoronnim-vhod-vospreshhjon (data obrashcheniya 17.10.15))

21. Makarov M.L. Dinamika sotsial'nykh predstavlenii v diskurse // Yazykovye podsistemy: stabil'nost' i dvizhenie: Sb. nauch. tr. Tver': Tver. gos. un-t, 2001. S. 64-71.

22. Iz zhizni ot"ezzhayushchikh // Lenta.ru. 14 iyulya 2014 g. (URL: http://lenta.ru/articles/2014/07/11/bezhentsy/ (data obrashcheniya 17.10.15))

23. Grafova L. Kak pomoch' ukrainskim bezhentsam obustroit'sya v Rossii // Rg.ru. 13 sentyabrya 2015 g. (URL: http://www. rg.ru/2015/08/02/bezhency.html (data obrashcheniya 12.09.15))

24. Slyshkin G.G. Ot teksta k simvolu: lingvokul'turnye kontsepty pretsedentnykh tekstov v soznanii i diskurse. M.: Academia, 2000.128 s.

25. Ya ne sobirayus' vozvrashchat'sya. My vsegda schitali sebya russkimi // Ruskline.ru 3 iyulya 2014 g. (URL: http://ruskline.ru/ news_rl/2014/07/03/ya_ne_sobirayus_vozvrawatsya_my_vsegda_schitali_sebya_russkimi/ (data obrashcheniya 17.10.15))

26. Bezhentsy vozvrashchayutsya iz RF na Donbass: ustali ot nishchety rossiiskoi glubinki i p'yanstva russkikh // Glavred. info. 7 aprelya 2015 g. (URL: http://glavred.info/zhizn/bezhency-vozvraschayutsya-iz-rf-na-donbass-ustali-ot-nischetyrossiyskoy-glubinki-i-pyanstva-russkih-312468.html (data obrashcheniya 17.10.15))

27. Byvshie sootechestvenniki vozvrashchayutsya v Rossiyu // News2.ru. 8 oktyabrya 2012 g. (URL: http://news2.ru/ story/364477/ (data obrashcheniya 17.10.15))

28. Sootechestvenniki vozvrashchayutsya v Rossiyu // Windowrussia.ruvr.ru. 4 noyabrya 2012 g. (URL: http://windowrussia. ruvr.ru/2012_11_04/Sootechestvenniki-vozvrashhajutsja-v-Rossiju/ (data obrashcheniya 17.10.15))

29. V Kareliyu vozvrashchayutsya sootechestvenniki iz Tadzhikistana, Moldovy i Gruzii // Russkie.org. 21 fevralya 2013 g. (URL: http://www.russkie.org/index.php?module=fullitem\&id=28559 (data obrashcheniya 17.10.15))

30. Vozvrashchenie sootechestvennikov v Rossiyu uskoryaetsya // Odnako.org. 10 oktyabrya 2013 g. (URL: http://www.odnako. org/blogs/vozvrashchenie-sootechestvennikov-v-rossiyu-uskoryaetsya/ (data obrashcheniya 17.10.15))

31. Russkie nemtsy pokidayut istoricheskuyu rodinu i vozvrashchayutsya v Rossiyu // Rg.ru. 8 iyunya 2007 g. (URL: http://www. rg.ru/2007/06/08/nemci.html (data obrashcheniya 17.10.15))

32. Russkie nemtsy vozvrashchayutsya v Rossiyu // Ru-an.info. 18 oktyabrya 2012 g. (URL: http://ru-an.info/novosti/russkienemtsy-vozvrashchayutsya-v-rossiyu/ (data obrashcheniya 17.10.15))

33. «Russkie nemtsy» v Germanii: uezzhayut tol'ko lentyai // Repin.info. 16 noyabrya 2012 g. (URL: http://repin.info/ nacionalnyy-otvet/russkie-nemcy-v-germanii-uezzhayut-tolko-lentyai (data obrashcheniya 17.10.15))

34. Pochemu vozvrashchayutsya «russkie nemtsy»? // Repin.info 30 oktyabrya 2012 g. (URL: http://repin.info/nacionalnyyotvet/pochemu-vozvrashchayutsya-russkie-nemcy (data obrashcheniya 17.10.15))

35. V Omskuyu oblast' massovo vozvrashchayutsya russkie nemtsy // Vesti.ru. 22 yanvarya 2013 g. (URL: http://www.vesti.ru/ doc.html?id=1011698 (data obrashcheniya 17.10.15))

36. Pochemu lyudi, pokinuvshie Rossiyu, vse ravno vozvrashchayutsya? // Okno.ca. 12 noyabrya 2015 g. (URL: http://okno.ca/ choice/pochemu-lyudi-pokinuvshie-rossiyu-vse-ravno-vozvrashhayutsya.html (data obrashcheniya 20.11.15))

37. Dolgii put' russkikh v Rossiyu // Nbm.md. 25 dekabrya 2013 g. (URL: http://nbm.md/news/main/dolgij_putj_russkuh_v_ rossiyu/default.aspx (data obrashcheniya 20.11.15))

38. Pochemu v Moskvu vozvrashchayutsya te, kto dolgo zhil za granitsei // The-village.ru. 10 oktyabrya 2012 g. (URL: http:// www.the-village.ru/village/city/people/117661-vernulis (data obrashcheniya 20.11.15))

39. Nasha perspektiva - Rossiya. Pochemu sootechestvenniki iz Germanii vozvrashchayutsya v Rossiyu? // www.russkie.org. 27 sentyabrya 2007 g. (URL: http://www.russkie.org/index.php?id=11242\&module=fullitem (data obrashcheniya 12.09.15))

40. Migrantov men'she ne stanet. // Lenta.ru 7 aprelya 2015 g. (URL: http://lenta.ru/articles/2015/04/07/migrant/ (data obrashcheniya 12.09.15))

41. Volokh V.A., Suleimanova Sh.S. Rol' i znachenie mediapolitiki v upravlenii migratsionnymi protsessami // Politika i obshchestvo. 2015. № 10. S. 1427-1433. (DOI: 10.7256/1812-8696.2015.10.15424)

42. Petukhov A.Yu. Vliyanie psikhologicheskikh operatsii na politicheskii protsess v Rossii v usloviyakh informatsionnykh voin // Natsional'naya bezopasnost' / nota bene. 2015. № 5. S. 648-655. (DOI: 10.7256/2073-8560.2015.5.16221)

43. Kirichek E.V.Politsiya i sredstva massovoi informatsii v Rossii: pravovoe regulirovanie, problemy i perspektivy vzaimodeistviya // Politika i obshchestvo. 2014. № 12. S. 1459-1468. (DOI: 10.7256/1812-8696.2014.12.10197)

44. Pashinyan I.A. Kontent-analiz kak istochnik otsenochnoi informatsii v issledovanii imidzha Rossii // Politika i obshchestvo. 2012. № 4. S. 108-113. 